\title{
COMMUNICATIVE LEARNING IN THE CLASSROOM INTERACTION (A DESCRIPTIVE STUDY ON THE TENTH GRADE STUDENTS IN MAN 3 TULUNGAGUNG IN THE 2016/2017 ACADEMIC YEAR)
}

\author{
Anis Azimah \\ English Education Department, IAIN Tulungagung \\ Email: anisazimah@ outlook.com
}

\begin{abstract}
This research aims at observing how the process of communicative learning occurred in the classroom interaction and identifying the types of interaction in the classroom. To meet the purposes of the research, this research raised the questions related to the principal features of Communicative Orientation of Language Teaching (COLT) scheme proposed by Nunan (1992). MAN 3 Tulungagung was taken as the setting of the research. The interaction between English teacher and students of Acceleration (X-10) class in the 2016/2017 academic year were recorded as the subject of the analysis. To examine the learning process and interaction, this research used qualitative approach in the form of descriptive method. In collecting the data, the researcher employed video recording. The data obtained through the observation was in the form of transcribed interaction. It was also found that the types of interaction occurred in the classroom are Teacher-Class (T - C), Teacher-Group (T-G), Teacher-Student(s) (T-S), and Student-Student (S$\mathrm{S})$ interactions. Each of this interaction is influential in the classroom. Regarding the findings of the research, the researcher concludes that these communicative analysis can be used as self-monitoring for English teacher to create communicative classroom. Therefore, this study is useful to introspect teacher's and learner's performance in the classroom.
\end{abstract}

Key words: communicative Learning, Classroom Interaction.

Received: 23 June, 2016; Accepted: 8 September, 2016

\section{INTRODUCTION}

Teaching learning process is an essential educational process involving so many elements work together as the wholeness in achieving certain instructional goal. Among the elements of the instructional process are teachers, learners, instructional objectives, materials, methods, instructional media, evaluation and many others. This process almost occurs in the classroom. Tsui (1995: 1) defines classroom as a place where more than two people gather together for the purpose of learning with one having the role of teacher. The teacher as one of the elements of the instructional process interacts with the other elements so that the instructional goal can be achieved. Classroom is also a unique context for learning and exerts a profound effect on students' development of language and literacy skills. 
Teaching learning process is the most common element in the language classroom. Language teaching can be simply defined as the activities aimed at bringing about learning. It can be assumed that language teaching is proposed to help people to learn and use language. According to Dewey in Risk (1958: 6), language teaching is the direction or the guidance of learning. Learning, on the other hand, is the acquisition of knowledge and skill. Thus, we can conclude that learning can be placed in appropriate definition as the learning to have knowledge and skill in language.

There are many ways in teaching and learning language. The way the teachers teach will influence the way the students learn. The latest approach to teach language is communicative approach. In communicative learning, in which language is thought in communicative way and for the purpose of effective communication, the teacher serves as more of a facilitator, allowing students to be in charge of their own learning. It also emphasizes reallife situations and communication in context.

Language learning occurs through meaningful interaction. Interaction simply means communication which implies more than one person. Interaction, then, will certainly involve students. In other words, it can be said that language learning is two-way interaction among all the elements in the classroom. Those elements play the same important role in determining whether the instructional goal is achieved or not. Each element cannot dominate each other. The teacher handles a significant role in creating an atmosphere that stimulates students to engage in the classroom since learning requires student interaction and engagement in classroom activities. The teacher has to plan certain activities and interactions in order to achieve a particular behavioural outcome. The same significant role is handled by the students. In language classroom, the students can be positioned both as the object or the receiver and the subject or one who can speak up, give ideas, and contribute to language in the classroom.

From the explanation above, we know that interaction in the language classroom is very important in teaching learning process. Classroom interaction contributes to the learning process simply by providing target language practice opportunities and the language itself is at once the subject of study as well as the medium of instruction. Communicative learning also will run smoothly if there is a good interaction between teacher and student. Therefore, understanding the interaction happening in communicative learning is also very important. Based on the reason above, the writer is interested to study the process of communicative learning especially in the classroom interaction-of tenth grade in MAN 3 Tulungagung.

\section{METHOD}

In this research, the writer uses qualitative method. It is one of special characteristics of qualitative research. Strauss and Corbin (1990: 17) state that qualitative research can refer to research about person's lives, stories, behaviour, organizational functioning, social movements, or interactional relationship. In qualitative research, according to Fraenkel \& Wallen (2000: 502) the researcher investigates the quality of relationship, activities, situations, or materials, while Nawawi \& Martini define qualitative research from its own characteristics; the data is shown in natural setting without any changes into symbols. From the definition, it can be concluded that qualitative research emphasizes more on the process of certain activity rather than the product. It has systematic data, scientific, and full of responsibility.

This qualitative method will be in form of case study since the study discussed is concerned with the teaching learning process in the classroom. According to Bogdan \& Biklen 
(1982: 58) a case study is a detailed examination of one setting or one single subject, or one single depository of documents, or one particular event. Further more, Patton (1983: 303) states that the case study approach to qualitative analysis is a specific way of collecting, organizing, and analysing data. The purpose is to gather comprehensive, systematic, and in-depth information about each case of interest. Moreover, Tuwu (1993: 73-74) states that a case study can be used to observe the individual's attitude deeply and holistically. It involves us with the smallest social unit such as schools or families. While Mulyana (2003: 200) defines case study as a description and explanation about many aspects of individual, group, organization, program, or social situation.

In this case study, what individual, group, organization, program, or social situation meant here is the process of communicative learning in the classroom interaction done by the teacher and the students. The researcher will observe as much as possible the object through interview, observation, and document analysis.

The data obtained from the field will be reported by using descriptive method. As stated by Moleong (2004: 6), one of the characteristics of qualitative study is descriptive. Fraenkel \& Wallen (2000: 553) state that descriptive method aims at documenting an event, situation, or circumstance. It is also commonly used in case study.

The technique used to analyse the data is very essential in a research. According to Patton (1980: 268) in Moleong (2000:103) data analysis can be interpreted as a process of ordering sequence of data and organizing them into a certain pattern, category, and single description.

In this research, the writer will employ interactive model of data analysis as suggested by Miles \& Huberman (2002: 16). It is a cyclical process of data analysis consisting three main components namely reduction of the data, presentation of the data, and conclusion or verification. The term cyclical here means that those three components of analysis are simultaneously done before, during, and after the data collection. It is in line with the major principal of the data analysis of qualitative research; interactive, analysis on the spot, and cyclical.

\section{FINDINGS AND DISCUSSION}

The research finding presents and discusses the answer of the research problem. Here, the data which have been obtained from the field are reported based on the observations, the interview with the teacher and the students of SBI class, and document analysis. The findings are focused on the communicative learning occurred in the classroom interaction and the types of interaction identified in the classroom

\section{Communicative learning occurred in the classroom interaction}

The communicative learning occurred in the classroom interaction is observed in four points of view, including the teacher, the students, the teaching learning process, and the materials.

\section{a. The teacher}

In the classroom interaction in which the communicative learning occurred, the teacher considered herself as facilitator during the whole lesson. It can be seen when the teacher presented the material in the PowerPoint slides, she did not just give the students materials dealing with the topic, but she preferred to combine her explanation together with questions 
JARES, Vol. 1 No. 2 September, 2016; p-ISSN: 2502-826X; e-ISSN: 2503-1163

Copyrights@ Balitar Islamic University, Blitar, Indonesia; Http://jares.unisbablitar.ejournal.web.id

Citation: Azimah, Anis . 2016. Communicative Learning In The Classroom Interaction (A Descriptive Study On

The Tenth Grade Students In Man 3 Tulungagung In The 2016/2017 Academic Year)

JARES, (2016), 1(2): 47-60

and answers so that there is two-way communicative interaction between the teacher and the students. The field note of the observation and of the interview illustrated it as follows

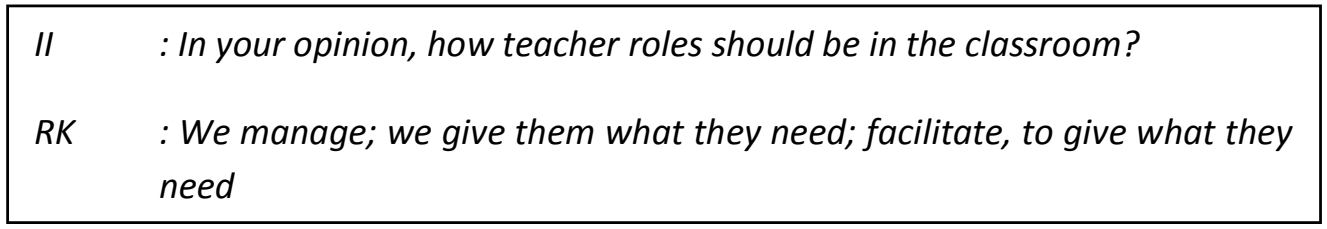

The teacher not only facilitates students' learning but also encourages them to be in charge of their own learning. For example, the teacher let the students to go on a dialogue related to the topic after explaining some language functions. She just gave some clues and let them develop the dialogue by themselves. By doing so, she encouraged her students to use English in a real context and to interact with their friends. It is in line with the example given bellow.

The teacher offered her students a game dealing with the topic invitation. She told the students the rules of the game as following: Now it's a game time. I have prepared an "ARISAN" pack here. I will give you each a piece of paper rolled in a straw, take one and pass it to the one next to you. Close your book and put it out. Do not open it first...Each student got a paper stating that they're invited or inviting to do a certain activity. Each paper has its pair so the student would go on a dialogue with their couple that they're not known before. Each student took turns in the game by inviting, refusing, persuading, hesitating, and finally accepting.

It shows that teacher's roles in the classroom interaction are neither dominant, nor less important. The teacher considered learning English as communication, so that she taught her students communicatively in order to make the students involved in the lesson. She tried to adjust the material with the students' need. She said that learning English is not about what we learn now but what we can apply later on.

For the students, the teacher is not only as the teacher but also the one who can place herself as a student too. The following evidence is taken from the transcript of the interview with students.

GP : Satu kelebihan yang dimiliki Miss RK yang mungkin tidak dimiliki guru-guru lainnya yaitu Miss RK mampu menyelami karakter murid-muridnya. Beliau mampu untuk mengnalisis sejauh mana siswa itu suka pada sesuatu, sejauh mana siswa tertarik pada sesuatu kemudian memunculkan ketertarikan itu dalam materi pelajaran. Beliau menempatkan dirinya sebagai siswa. Dengan mencoba menjadi siswa mengetahui apa yang siswa inginkan dan senangi sehingga kelas bisa menjadi lebih dinamis.

TA : Sama seperti saudara Gineng, Miss. RK itu mencoba mendekatkan diri pada muridnya sehingga tercipta suatu suasana yang tidak monoton, lebih dinamis, santai dan fleksibel. 
JARES, Vol. 1 No. 2 September, 2016; p-ISSN: 2502-826X; e-ISSN: 2503-1163

Copyrights@ Balitar Islamic University, Blitar, Indonesia; Http://jares.unisbablitar.ejournal.web.id

Citation: Azimah, Anis . 2016. Communicative Learning In The Classroom Interaction (A Descriptive Study On

The Tenth Grade Students In Man 3 Tulungagung In The 2016/2017 Academic Year)

JARES, (2016), 1(2): 47-60

From the excerpt, it is obvious that the teacher place herself not as the leader of the class who knows about everything but as a student who also needs to learn. By doing so, the students felt comfortable to interact with the teacher. It creates a dynamic, flexible, and fun but not monotonous classroom interaction.

\section{b. The students}

Students are the central of learning activity. They interact a great deal in various configurations including pairs, triads, small group, and whole group. From the observation, it can be identified that the students engaged in various classroom activities. They're trying to respond to the teacher's questions, they're trying to comprehend the teacher's explanation by listening carefully or even asking questions. The example of the student's responding to the teacher question can be identified in the excerpt below.

\begin{tabular}{|ll|}
\hline $\mathrm{T}$ & : So between the medias, which one is more enjoyable, more relaxing? TV or \\
& news paper? \\
$\mathrm{Ss}$ & $:$ TV \\
$\mathrm{T}$ & $:$ From the TV. Why do you say so? Yeah Nabila! \\
$\mathrm{S}$ & $:$ From the TV we have videos, but in news paper just photograph \\
$\mathrm{T}$ & $:$ Aha, so not all news, each has its own photo. And then?
\end{tabular}

Students are free to express their ideas and opinion, but it is true that not all students are confident in expressing their own ideas. Some of them admitted that they feel confident to ask anything they don't know to their teacher or even to convey their ideas. But for those who are silent, it's the teacher's turn to encourage them to be more active in the classroom so that they can participate as equal as the other students. Related to this, the teacher explained the students' response toward her language

RK So far they give me the respond that I want. Well there are exceptions for
some students who are well, slow learners. Some of them are very quickly in
understanding because they have a good basic in English too, some of them
are very good in mathematics and other sciences but they're bad in English,
there're some of them too, but I try to convey what they need. I give
attention to those need attention and I will let go up those who had already
know it, why should I accompany them all the time? For some students who
are already good I will let them do whatever they do, but for those who need
guidance I'll come and help. Let say I keep saying if you need help just talk
and then I'll go around and not just in front of the classroom sit down and
do nothing and I try my best to let my voice flow through the classroom, they
all listen to me without having to say "what did the teacher say?"


Another students' involvement can be identified when they were actively engaged in pair work activity such as games and role play. In the first observation the students involved in a game related to the topic "invitation". Then in the second observation, the teacher asked the students to take role as news anchor since the lesson was related to news item and in the third observation, whispering game related to the topic reported speech became one of learning activities in the classroom interaction. The teacher wanted the students to experience everything in learning English by themselves so that they can feel that learning English is enjoyable.

\section{c. The teaching learning process}

Functional communication activities and social interaction activities are types of learning activities that engage learners in authentic communication. Games and role play are the most recognizable features in the classroom interaction. They develop students' language skills which involve communication. They also focus not only on conveying meanings effectively, but also paying greater attention to the social context in which the interaction takes place. The teacher employed games and role play in order to relate the topic with the students' world. The following excerpt shows that communicative games can be considered as an effective way in learning English.

II : Next about the teaching technique, I observed in the classroom that you
let the students take role as news anchor. What are the other techniques
you used in the classroom?
RK : Games, of course. Last time we're having a game called "TREASURE
HUNTING" they have to hide a piece of paper or something that they call
as treasure and they have to hide in the class and they make a map. The
map only says turn right, turn left but it's just in symbols because I teach
them imperative and prepositional phrase. So turn right, turn left, go up
and down, look up, look down, it's under the chair, it's on the top of the
book just like that.

During the observation, the observer found that the teacher initiated classroom activities with explanation in combination with questions and answers. She sometimes gave her students feedback. It creates an interaction between the students and the teacher.

English is used by both teacher and students almost during the lesson. It shows that English is both as the medium of instruction and the target language. Although the native language still appeared in the classroom activities, it's less dominant.

Learning English cannot be separated from four language skills. From the appearance of the check marks on the scheme, there's no exclusive language skill taught by the teacher. In the first observation, speaking became the primary focus of the lesson while listening activity was going on, while in the second observation reading was emphasized although it's in combination with listening and speaking. In the third observation the observer identifies that the teacher focused on writing since the students engaged in writing the draft of news. In short, it can be said that the teacher combined the four language skills in the classroom activities in order to encourage her students to integrate their skills practice to reflect a more authentic use of language. Related to this, the teacher explained as follows: 
JARES, Vol. 1 No. 2 September, 2016; p-ISSN: 2502-826X; e-ISSN: 2503-1163

Copyrights@ Balitar Islamic University, Blitar, Indonesia; Http://jares.unisbablitar.ejournal.web.id

Citation: Azimah, Anis . 2016. Communicative Learning In The Classroom Interaction (A Descriptive Study On The Tenth Grade Students In Man 3 Tulungagung In The 2016/2017 Academic Year)

JARES, (2016), 1(2): 47-60

\begin{tabular}{|c|c|}
\hline II & $\begin{array}{l}\text { : Since language consists of four language skills, do you emphasize } \\
\text { certain skill in teaching the students? }\end{array}$ \\
\hline $\mathrm{RK}$ & $\begin{array}{l}\text { :Not emphasizing actually. I'd rather say combining. If you're teaching } \\
\text { reading, it doesn't mean you may not teaching listening, no, you can } \\
\text { teach listening in reading, you can teach speaking while reading, you } \\
\text { can teach writing while reading. Reading can go anywhere as well as } \\
\text { writing. But for writing in first grader I emphasize on making } \\
\text { composition, from word, to sentence, to paragraph, to composition. I } \\
\text { try to make it that way. }\end{array}$ \\
\hline
\end{tabular}

\title{
d. The materials
}

The materials used by the teacher were typically extended since the teacher didn't limit the teaching materials merely on the text book. She even didn't use it during the observation. She used authentic material like newspaper. She also employed audio visual material such as short movie and self-prepared material like PowerPoint slides with funny pictures and interesting color. The following excerpt illustrates why the teacher used such materials.

\section{II : How about teaching media? While observing your class I knew that you used many teaching media like PowerPoint slides with many interesting pictures in it. Any other teaching media that you use in the class?}

\begin{abstract}
RK : Well, teaching media. I rarely touch the book because I want the kids to be what's it, ah it's going to be fun, I want them to be exited waiting for my lesson, oh she's coming. What will she give? So I'm trying not to make them bored because boredom kills the lesson, for sure. When you're bored, when somebody ask you so what did you learn? Ah nothing it's like when will it end? When will it end? Come on please the bell ring. And when the bell ring they will say oh God thank you, finally the bell rings and that's not what I want, I want the kids ah... the lesson ended, ah... I want to have it again, when they're excited to learn something because I used to be in high school where the teacher's so boring and I don't want my students to feel the same with me too, so I try to use as many sources as I can to get the media that I want, anything that's good for my kids. When anything means anything, I don't limit it to books. Why not magazine? Why not newspaper? Something that can be used in real life. Why not video or internet.
\end{abstract}

From the teacher explanation, it can be identified that the teacher tried to motivate the students to get involved in the lesson by providing unrestricted materials. Anything that can be used to influence the quality of classroom interaction and language use and to achieve good 
JARES, Vol. 1 No. 2 September, 2016; p-ISSN: 2502-826X; e-ISSN: 2503-1163

Copyrights@ Balitar Islamic University, Blitar, Indonesia; Http://jares.unisbablitar.ejournal.web.id

Citation: Azimah, Anis . 2016. Communicative Learning In The Classroom Interaction (A Descriptive Study On

The Tenth Grade Students In Man 3 Tulungagung In The 2016/2017 Academic Year)

JARES, (2016), 1(2): 47-60

learning outcomes is allowed. Dealing with teaching media the students mentioned various materials as follows:

\begin{tabular}{|ll|}
\hline II & : Media apa yang biasa digunakan oleh Miss RK dalam mengajar? \\
TA $\quad$ :Ya selain PowerPoint slide, Miss RK menggunakan apa yang ada di sekitar \\
kP $\quad$ : Saya ingat walitas yang ada di kelas. \\
alat-alat game yang dibuat sendiri oleh Miss RK misalnya scroll paper. \\
NB $\quad$ Kalau saya sama seperti apa kata Gineng dan Tatang, jadi kadang media \\
itu ada tanpa kita mengeluarkan modal apapun. Kayak misalnya pas \\
deskripsi dan preposisi, kita gunain benda-benda yang ada disekitar kita. \\
Miss RK cuma bilang kalian perhatikan benda-benda di sekeliling kalian dan \\
deskripsikan. Itu kan kita gak butuh modal apa-apa selain how to imagine
\end{tabular}

By using various materials, the students would be more interested to learn since they could experience something new that they couldn't find if they learned merely based on the text book.

\section{Types of interaction identified in the classroom}

The types of interaction identified in the classroom were analyzed from the COLT observation scheme. In part A, when the coding process was done during the observation, the observer identified that the interaction happened between the teacher to students or class while the teacher's explaining the material together with questions and answers. She spent some time of the entire class time interacting exclusively with the whole class or individual students in each lesson ( $\mathrm{T} \quad \mathrm{S} / \mathrm{C})$. She also interacted with group of students during the lesson. The teacher interacted with the students by initiating questions and answering student's question

There are some students who were interacting with the whole class or individual students while one central activity was going on ( $\mathrm{S} \quad \mathrm{S} / \mathrm{C})$. It can be seen when pairs of students take role as news anchor and play game dealing with the topic intvitation". The students were also involved in individual work focusing on the same tast? The most important thing is that the students interacted in group work focusing on the same task when they were involved in the game and role play. It is no doubt that in communicative learning, group work interaction is considered to be essential in developing communicative competence. But not all students enjoyed group work. The following excerpt illustrates it 
JARES, Vol. 1 No. 2 September, 2016; p-ISSN: 2502-826X; e-ISSN: 2503-1163

Copyrights@ Balitar Islamic University, Blitar, Indonesia; Http://jares.unisbablitar.ejournal.web.id

Citation: Azimah, Anis . 2016. Communicative Learning In The Classroom Interaction (A Descriptive Study On

The Tenth Grade Students In Man 3 Tulungagung In The 2016/2017 Academic Year)

JARES, (2016), 1(2): 47-60

II Dalam belajar bahasa Inggris mana yang lebih kalian senangi, group
Work atau individual work?
: Kalau saya lebih condong ke individual work karena lebih menuntut
keahlian kita
: Kalau saya group work karena jujur dalam satu group itu pasti ada
yang lebih dan ada yang kurang, nah dengan group work ini yang lebih
diharapkan mampu memberikan subsidi silang kepada yang kurang,
dan yang kurang bias lebih mengeksplor kekurangan yang ada pada
dirinya sehingga tercipta interaksi timbal balikyang baik yangbaik antar
sesame anggota dalam satu group
: Kalau saya lebih suka yang individual karena kalau menurut Gineng
dengan subsidi silang itu bagus, tapi menurut saya itu kasihan yang
nilainya menonjol karena akan terlihat sama dengan yang kurang tapi
padahal jika dalam satu group apalagi kalau sudah terlalu banyak
orang, itu yang kerja paling gak lebih dari tiga orang padahal groupnya
ada 7-8 orang jadi kan kasihan juga mereka udah ngrajain tapi nilainya
disamakan dengan yang lain. Tapi bukan berarti group itu selalu buruk
karena suatu saat kita juga pasti butuh group work untuk
berkomunikasi dan bekerja sama dengan orang lain. Misalnya saja
dalam games yang melibatkan komunikasi didalamnya.

During the observation, the observer didn't find the teacher used text book so that there's no indirect interaction between the teacher and the students mediated by the text book.

The interaction mostly occurred in the form of verbal interaction. It is identified from the COLT observation scheme part B. The coding and the analysis were done after the observation. The observer prepared a transcript of the learning act from video recording. The transcript was used to analyze the verbal interaction between the teacher and the students. It is characterized by seven features namely target language, information gap, sustained speech, reaction to form/message, incorporation of students/teacher utterance, discourse initiation, and form restriction. The last two features were coded only for student verbal interaction.

From the data coded, the writer found that the information gap of the teacher's verbal interaction was in form of giving and requesting information. The information requested mostly in form of the genuine one, meaning that the answer is not known in advance. She gave information while presenting the material. The utterances produced by the teacher were mostly identified as minimal although there are some sustained turns, that are when the teacher produced utterances more than two clauses or sentences. She also reacted both to form and message conveyed by her students. Moreover, related to incorporation of students' utterance, the various ways in which teacher reacted to the students' utterance, the writer analyses seven categories coded from the transcript. Among them are correction, repetition, paraphrase, 
comment, expansion, elaboration request and clarification request. It is coded in combination with message and under the feature of reaction to form or message. The writer can identify that the teacher sometimes combined reaction to form or message with the use of correction and repetition, correction and paraphrase, comment, expansion, clarification requests, and elaboration requests, but it is dominated by reaction to message in combination with expansion and elaboration request. It is intended to elicit more information from the students. The limitation of this feature is that each category is not sufficient to describe every feature of an utterance which occurs in the discourse although the categories under this feature allow for some distinction between the kinds of interactions between the teacher and the students. The teacher verbal interaction is almost all in English. As the additional category, off task emerged as non communicative feature, that is anything unrelated to the curricular activities such as teacher's giving punishment for the late comers.

Student verbal interaction is almost similar with that of the teacher. It is reflected in the students' giving or requesting for information from the teacher. Mostly, the students gave unpredictable information toward the teacher's request. It means that self-initiated questions by the students are rare. The difference is that the production of the language which is still minimal or even ultra minimal meaning that most of the students' turns consist only one or two words, long phrases, or one to two main clauses or sentences only. Although not all utterances produced by students are in English, but it's not too significant. The writer identified that in average the students could comprehend what the teacher tried to convey. The two remaining features of verbal interaction refer to student only, discourse initiation-self-initiated turns by students, and form restriction or the extent to which the language the students produce was restricted in terms of linguistic form. During the observation the self-initiated turns by the students existed but they rarely occurred. The examples are given in the transcript. Form restriction of the students' utterances is both restricted and unrestricted. It depends on the topic being discussed. For example, when the teacher asked the students about how to invite someone then the students' utterances will be restricted only to several expression such as would you like to...? or how about...? It is different when the teacher asked for an opinion from the students, the students' utterances then will be in unrestricted form.

\section{Discussion}

In order to justify the research finding, the writer tries to discuss it with the other relevant references.

\section{Communicative learning occurred in the classroom interaction}

Communicative learning is the way in which the learners learn for the purpose of communication. It is based on the assumption that communication is the ultimate goal of language teaching and learning. Learning English for communication is influenced by the approach namely Communicative Language Teaching. One of the most recognizable features of it is an emphasis on learning to communicate through interaction in the target language. Since the teacher, the students, the teaching learning process, and the materials are the most common aspects in the classroom interaction, the discussion of the communicative learning in the classroom interaction was seen from those dimensions.

The writer found that in the classroom interaction in which communicative learning is occurred through several ways, the teacher served as facilitator for her students. She guided the students to be in charge of their own learning by letting the students to experience the learning 
process by themselves. It is in line with one of the principles of CLT stated by Larsen and Freeman (2000: 17) that teacher acts as a facilitator in setting up communicative activities and as and advisor during the activities.

The teacher made the students to become the center of learning activities. It is a good point that the teacher knows how to place herself in the class so that the interaction can keep on going well.

From the students' point of view, the writer found that they interacted a great deal with one another even with the teacher in various manners including pair work or small group. Since the students are the center of learning activity, they're free to express their ideas and opinion by using the target language. As stated by Larsen and Freeman (2000: 19) students are, above all, communicators. They are actively engaged in negotiating meaning - in trying to make themselves understood and in understanding others - even when their knowledge of the target language is incomplete. Based on the observation, it can be seen that the students tried to be actively engaged in the learning activities by applying what they have got from the teacher with their prior knowledge. Related to this, the writer assumes that the students have a relatively good basic knowledge in English so that it is not a big deal for them to use English during the lesson.

In term of teaching learning process, the emphasis should be on the process of communication rather than just on the mastery of language content. It can be identified in the classroom activity when the teacher presented the material in combination with questions and answers. It showed that there's two-way communicative interaction between the students and the teacher. It can also be seen when the students got involved in the game. The teacher emphasized on how the students can keep on going in the dialogue rather than on how the students' language is. The teacher considered errors as outcome of the development of communication skills. Functional communicative activities and social interaction activities are the ideal types of communicative learning activities. They are reflected in the use of game and role-play as part of the learning activities. Since it is communicative learning, the content of the language that is introduced first is language functions rather than language forms. The students then worked on four language skills. It is identified that the teacher engaged the students to combine those skills in various activities. For instance, while discussing news item in which the focus was on reading, the teacher engaged the students to write news draft, so that writing skill was included here, or while presenting certain material in which the students were expected to listen, the teacher combined it with question and answer. The students worked not only in one exclusive language skill but also combined the skills in one central learning activity. Ideally the students also worked with language in the level of the discourse, but during the observation, the writer didn't find the students worked on written discourse, but the teacher implied in the interview that the students were about making composition too. Therefore, the writer assumes that written discourse is the part of learning activity too.

Authentic materials are emphasized in communicative learning. It includes text-based materials, task-based materials, and realia, something that can be used in real life. Richard and Rodgers (1993: 79-80). Newspaper, magazine, PowerPoint slides, cartoon film, short movies, self-prepared material, comics features are various materials used by teacher to make the students interested in learning English. The teacher provided materials that are closely related to the students' world. It can be seen from some students' statement that they enjoyed in joining the teaching- learning process. The materials used by the teacher and the students are not 
restricted to the text book. The teacher even admitted that she rarely touched the book since she argued that when learning just comes only from the text book, it will create boredom. The teacher tried to use as many sources as she can in order to make a dynamic classroom interaction.

\section{Types of interaction identified in the classroom}

Classroom interaction is the actions interrelated and performed by the teacher and the learners during instructional process. It contributes to language development simply by providing target language practice opportunities since in the language classroom language is at once the subject of study as well as the medium for learning.

From the observation, the writer identified that the interaction occurred between teacher and student or class. It means that one activity led by the teacher occurs; the teacher interacts with the whole class and/or with individual student within a central activity. There's also student to student, or student to class interaction, meaning that one central activity led by a student or students occurs. The interaction also occurred in pair work or small group activities.

In terms of verbal interaction, it is found that the teacher verbal interaction includes giving and requesting information from her students. Most of the language produced by the teacher is minimal and sustained. She reacted both to the form and the message conveyed by the students. It deals with the content of part A COLT observation scheme. Related to the incorporation of students' utterances, the teacher reacted to the students' previous utterances under seven categories namely correction, repetition, paraphrase, comment, expansion, and clarification request. Sometimes, it was used in combination among them. All the utterances produced by the teacher are in the target language, English. As the additional category, that is not a communicative feature, off task is reserved for verbal interaction unrelated to the curricular activities. It reflected when teacher gave a punishment to those who came late and the other determined the kind of the punishment.

Almost similar, students' verbal interaction reflected when the students were giving or requesting for information from the teacher. The difference is that their production of the language is still minimal. It means that most of the students' turns consist only one or two words, long phrases, or one to two main clauses or sentences only. The students also reacted both to the form and the message conveyed by the teacher. Moreover, the incorporation of teacher's utterances mostly occurred under the categories repetition, comment, and clarification request. Not all utterances produced by students are in target language, but it's not too significant since in average they could comprehend what the teacher tried to convey. The two remaining features of verbal interaction belong to students only. They are discourse initiation, self-initiated turns by students, and form restriction or the extent to which the language the students produce is restricted in terms of linguistic form. During the observation the selfinitiated turns by the students existed but they rarely occurred. Form restriction of the students' utterances is both restricted and unrestricted. It can be seen, for example when a student was reading aloud a text or in questions and answers session. It depends on the topic being discussed.

\section{CONCLUSION}

Based on the research finding and the discussion, the writer concludes that communicative learning really occurs in the classroom where the observation was conducted. It is based on the teacher's assumption that teaching English aims at effective communication. Beside it is also proved by some students that they learn English in order to apply it in real life. 
JARES, Vol. 1 No. 2 September, 2016; p-ISSN: 2502-826X; e-ISSN: 2503-1163

Copyrights@ Balitar Islamic University, Blitar, Indonesia; Http://jares.unisbablitar.ejournal.web.id

Citation: Azimah, Anis . 2016. Communicative Learning In The Classroom Interaction (A Descriptive Study On

The Tenth Grade Students In Man 3 Tulungagung In The 2016/2017 Academic Year)

JARES, (2016), 1(2): 47-60

The communicative learning occurred in the classroom interaction can be identified first from the teacher that takes a role as the facilitator for the students. It means that the teacher gives guidance for the students in order that they can be autonomous learners, those who are in charge of their own learning. The second, communicative learning can be seen from the students when they interact a great deal in various configurations, especially in pairs or small group, both with the teacher and the other students. It can be identified that the students were actively engaged in various classroom activities. The third, the teaching learning process contributes to the communicative learning simply by providing functional communication activities and social interaction activities such as communication games and role-play. The fourth, the teacher provides unrestricted materials to make the students get involved in the lesson. The materials include realia such as newspaper and other materials that are closely related to the students' life, for example cartoon movie, and comic features.

The types of interaction can be identified in the classroom activity between the teacher and the students or class and student to student, or student to class interaction. Last but not least, the most recognizable interaction is in the form of verbal interaction between both the teacher and the students. It can be identified among the features in COLT observation scheme under several categories.

\section{References}

Bogdan, Robert C and Biklen, Sari Knopp. 1982. Qualitative Research for Education: An Introduction to Theory and Methods. Boston: Allyn and Bacon.

Fraenkel, Jack E. and Wallen, Norman E. 2000. How to Design and Evaluate Research in Education. USA: McGraw-Hill Companies Inc.

Hadi, Sutrisno. 2004. Metodologi Research. Yogyakarta: Penerbit Andi.

Larsen, Diane and Freeman. 2000. Techniques and Principles in Language Teaching. New York: Oxford University Press.

Littlewood, William. 1992. Communicative Language Teaching. New York: Cambridge University press.

Miles and Huberman. 2002. Analisis Data Kualitatif. Jakarta: UI Press

Moleong, Lexy J. 2000. Metodologi Penelitian Kualitatif. Bandung: PT Remaja Rosdakarya.

Mulyana, Dedy. 2003. metodologi Penelitian Kualitatif. Bandung: PT Remaja Rosdakarya.

Nawawi, Hadari H and Martini, Mimi H. 1994. Penelitian Terapan. Yogyakarta: Gadjah Mada University Press.

Nunan, David. 1991. Communicative Tasks and the Language Curriculum. TESOL Quarterly.

Patton, Michael Quinn. 1983. Qualitative Evaluation Methods. London: Sage Publication.

Richards and Rodgers. 1993. Approaches and methods in Language Teaching. Cambridge: Cambridge University Press.

Rivers, Wilga M. 1987. Interactive Language Teaching. Cambridge: Cambridge University Press.

Savignon, Sandra J. 1997. Communicative Competence Theory and Classroom practice. Pennsylvania: Mc Graw Hill.

Strauss, Anselm and Corbin, Juliet. 1990. Basic of Qualitative Research: Grounded Theory, Procedures, and Technique. London: Sage Publication.

Tsui, Amy BM. 1995. Introducing Classroom Interaction. London: Penguin Group. 
JARES, Vol. 1 No. 2 September, 2016; p-ISSN: 2502-826X; e-ISSN: 2503-1163

Copyrights@ Balitar Islamic University, Blitar, Indonesia; Http://jares.unisbablitar.ejournal.web.id

Citation: Azimah, Anis . 2016. Communicative Learning In The Classroom Interaction (A Descriptive Study On The Tenth Grade Students In Man 3 Tulungagung In The 2016/2017 Academic Year)

JARES, (2016), 1(2): 47-60

Tudor, Ian. 1996. Learner-Centredness as Language Education. Cambridge: Cambridge University Press.

Tuwu, Alimuddin. 1993. Pengantar Metode Penelitian. Jakarta: UI Press. 